\title{
Natural Indicator for Acid-Base Titration from Thai Yellow Flower Extracts
}

\author{
Naruwan Pattarapongdilok, Primpak Malichim, Natthaphol Simmee, and Jirapast Sichaem
}

\begin{abstract}
This study was aimed at investigating the efficiency of extract indicators from three yellow flowers in Thailand (Acacia auriculiformis A. Cunn., Crotalaria juncea $\mathbf{L}$. and Sesbania javanica Miq.). The flowers were extracted with deionized water and evaporated in order to get dried extracts. The flower extracts $(5 \% \mathrm{w} / \mathrm{w})$ were prepared as indicator. In the primary experiment, the flower extracts were tested in order to determine their indicator property using three types of solutions, different $\mathbf{p H}$, buffer solutions, $\mathrm{HCl} / \mathrm{NaOH}$ solutions and $\mathrm{CH}_{3} \mathrm{COOH} / \mathrm{NaOH}$ solutions. The results show that the colors will be changed in basic solution. Then, the indicator activities of flower extracts were used in acid-base titration in which a strong base was used as a titrant and the results were compared using a standard indicator, phenolphthalein. The results suggest that the flower extracts can be used as an alternative indicator for strong acid $(\mathrm{HCl})-$ strong base $(\mathrm{NaOH})$ titration and weak acid $\left(\mathrm{CH}_{3} \mathrm{COOH}\right)$ - strong base $(\mathrm{NaOH})$ titrations. The color of solution will be changed from light brown to dark brown for A. auriculiformis A. Cunn., and transformed from light brown into yellow for $C$. juncea $L$. and $S$. javanica Miq. when the solutions have more basicity. The color changes were clear and sharp when the strength of $\mathrm{NaOH}$ solution was increased. Therefore, the use of these flowers' extracts as indicators is their new application which can be applied in the chemistry class because these natural indicators are safe, cheap and easy to prepare.
\end{abstract}

Index Terms-Acacia auriculiformis A. Cunn., crotalaria juncea L., sesbania javanica Miq., acid-base titration, natural indicator.

\section{INTRODUCTION}

Titration or titrimetry is a general laboratory method of quantitative chemical analysis which can be observed from the quantity of a liquid of standard solution, the titrant or the solution of known concentration, to convert the constituent into another form [1]-[3]. A change of color or the formation is used to determine the concentration of an analyte, titrand or unknown solution [2]. The method of quantitative analysis of acid and base by an acid or base of standard solution exactly

Manuscript received November 30, 2018; revised January 28, 2019.

This work was supported by the grant from Bansomdejchaopraya Rajabhat University, Thailand.

Naruwan Pattarapongdilok is with Chemistry Program, Department of Science, Faculty of Science and Technology, Bansomdejchaopraya Rajabhat University, Bangkok 10600, Thailand (e-mail: olinpoo@gmail.com).

Primpak Malichim and Natthaphol Simmee were with Science Program, Faculty of Education, Bansomdejchaopraya Rajabhat University, Bangkok 10600, Thailand (e-mail: primpak31@gmail.com, natthaphon603@gmail.com).

Jirapast Sichaem is with Department of Chemistry, Faculty of Science and Technology, Thammasat University Lampang Center, Lampang 52190, Thailand (e-mail: jirapast.s@gmail.com). neutralizing with an acid or base of unknown concentration is called an acid-base titration [3], [4]. The equivalent point is very difficult to observe because the reaction between an acid and base will yield colorless salt and water. Acid-base indicators, also known as $\mathrm{pH}$ indicators, are usually weak acids or bases, which when dissolved in water dissociate slightly and form ions. A good indicator is a weak acid or weak base that is slightly soluble in water. The commercial indicators are relatively expensive and have a toxic effect on the user and can also cause environmental pollution [5].

Therefore, a lot of research is focusing on an alternative to substitute the commercial indicators. The alternative needs to have the end point and equivalence point volumes coinciding closely for low titration error. Moreover, it should be cheaper, more available, easier to be extracted, less toxic to the user and environmentally friendly. A natural indicator is a natural substance typically from a plant origin that can be used to determine the $\mathrm{pH}$ of another substance [6].

Nerium indicum and Aspilia africana extracts can be used as acid-base indicators that can replace phenolphthalein (indicator) because it is easy to find and prepare and yields precise and accurate results [7]. In addition, Rosa setigera, Allamanda cathartica and Hibiscus rosa-sinensis had been effectively used as a substitute for commercial indicators [8].

A. auriculiformis A. Cunn. (Fabaceae) is an important medicinal plant and is a well-known source of phenolics, tannins and terpenoids. This plant has been used as natural medicine for the treatment of anti-helminthes, antifungal and anti-microbial effects [9].

C. juncea L., commonly known as brown hemp, Indian hemp, Madras hemp, or sunn hemp, belong to Fabaceae family. This plant possesses hypolipidemic, reproductive, antioxidant, antibacterial, antifungal, antidiarrheal, antiinflammatory, hepatoprotective and many other pharmacological effects. Its leaves showed the presence of carbohydrates, steroids, triterpenes, phenolics, flavonoids, alkaloids, aminoacids, saponins, glycosides, tannins and volatile oils [10].

S. javanica Miq. (Fabaceae) commonly known as "Sano" in Thai or "Phak hong hang" (northern Thai). Its flowers are harvested only in the rainy season and commonly consumed in Thailand. In ancient Thai traditional medicine, it was used as an anti-inflammatory for insect bites, detoxification, intestinal abscess healing, stomach discomfort and to relieve internal fever and thirst. The major flavonoids in S. javanica Miq. flower extracts are the flavonol glycoside and Quercetin 3-2G-rhamnosylrutinoside [11].

A. auriculiformis A. Cunn., C. juncea L. and S. javanica Miq. have the same natural product chemical that can 
generate colors in the acid-base solutions such as flavonoid. The flavonoid has subgroups which are the color pigments such as anthocyanins and flavonones [12], [13]. It is interesting to use it as an indicator in acid-base titration.

Hence in this study, we aim to evaluate the properties of some natural substances such as A. auriculiformis A. Cunn., $C$. juncea $\mathrm{L}$. and S. javanica Miq. flowers in order to ascertain their analytical potentials as indicators.

\section{MATERIALS AND METHODS}

\section{A. Materials}

The three flowers were collected from different places in Thailand. Northern black wattle flowers (A. auriculiformis A. Cunn., AAC) and Sunn hemp flowers (C. juncea L., CJL) were collected from Kalasin province. Sesbanea pea flowers (S. javanica Miq., SJM) were collected from Bangkok. The flowers were stored in a dried form. Fresh petals were separated from flowers and cut into small pieces. They were cleaned with deionized water and dried at $60{ }^{\circ} \mathrm{C}$ for two hours. All chemicals and reagents used in this investigation were of analytical grade.

\section{B. Methods}

Exactly 6 grams of dried petals of flowers (A. auriculiformis A. Cunn., C. juncea L. and S. javanica Miq.) mixed with $200 \mathrm{~mL}$ of deionized water were heated at $100{ }^{\circ} \mathrm{C}$ for one hour. The aqueous extracts were filtered by a filter paper, Whatman 1 , and evaporated through a vacuum rotary evaporator at $60{ }^{\circ} \mathrm{C}$. The extract indicators for study were prepared using $5 \%(\mathrm{w} / \mathrm{w})$ of dried extracts in water.

The color change of the extracts was observed by adding five drops of flower extracts into $6 \mathrm{~mL}$ of different $\mathrm{pH}$ solution of buffer solutions, hydrochloric acid/sodium hydroxide $(\mathrm{HCl} / \mathrm{NaOH})$ solutions, and acetic acid/sodium hydroxide $\left(\mathrm{CH}_{3} \mathrm{COOH} / \mathrm{NaOH}\right)$ solutions. The buffer solutions were prepared using mixtures of hydrochloric acid/potassium chloride $(\mathrm{HCl} / \mathrm{KCl})$ for $\mathrm{pH}$ values $1,2,12$, and 13, hydrochloric acid/potassium hydrogen phthalate ( $\mathrm{HCl} / \mathrm{KHP}$ ) for $\mathrm{pH}$ values 3 and 4 , potassium hydrogen phthalate/sodium hydroxide $(\mathrm{KHP} / \mathrm{NaOH})$ for $\mathrm{pH}$ values 5 , potassium dihydrogen phosphate/sodium hydroxide $\left(\mathrm{KH}_{2} \mathrm{PO}_{4} / \mathrm{NaOH}\right)$ for $\mathrm{pH}$ values from 6 to 8 , hydrochloric acid/sodium tetraborate decahydrate $\left(\mathrm{HCl} / \mathrm{Na}_{2} \mathrm{~B}_{4} \mathrm{O}_{7} \cdot 10 \mathrm{H}_{2} \mathrm{O}\right)$ for $\mathrm{pH}$ values 9 , and hydrochloric acid/sodium bicarbonate in $\mathrm{pH}$ values 10 and 11 [14], [15]. The $\mathrm{HCl} / \mathrm{NaOH}$ solutions and $\mathrm{CH}_{3} \mathrm{COOH} / \mathrm{NaOH}$ solutions have various $\mathrm{pH}$ values from 1 to 14 .

Acid-base titrations with flower extracts were carried out using $15 \mathrm{~mL}$ of $1.0 \mathrm{M} \mathrm{HCl}$ as a titrand, and $0.5 \mathrm{M} \mathrm{NaOH}$ and $1.0 \mathrm{M} \mathrm{NaOH}$ as a titrant for strong acid-strong base titration. $15 \mathrm{~mL}$ of $1.0 \mathrm{M} \mathrm{CH}_{3} \mathrm{COOH}$ solution, and $0.5 \mathrm{M}$ and $1.0 \mathrm{M}$ $\mathrm{NaOH}$ were used for weak acid-strong base titration. We used the $50-\mathrm{mL}$ beaker to replace the Erlenmeyer flask and used a magnetic bar for stirring during titration. KHP was used as a primary standard for determining concentration of $\mathrm{HCl}$ and $\mathrm{CH}_{3} \mathrm{COOH}$ solutions. The results were compared using phenolphthalein (three drops per sample) as a standard indicator. The mean and standard deviation for each type of acid-base titrations were calculated from the results of trials repeated for five times. Moreover, there is measurement of $\mathrm{pH}$ range for each sample by $\mathrm{pH}$ meter.

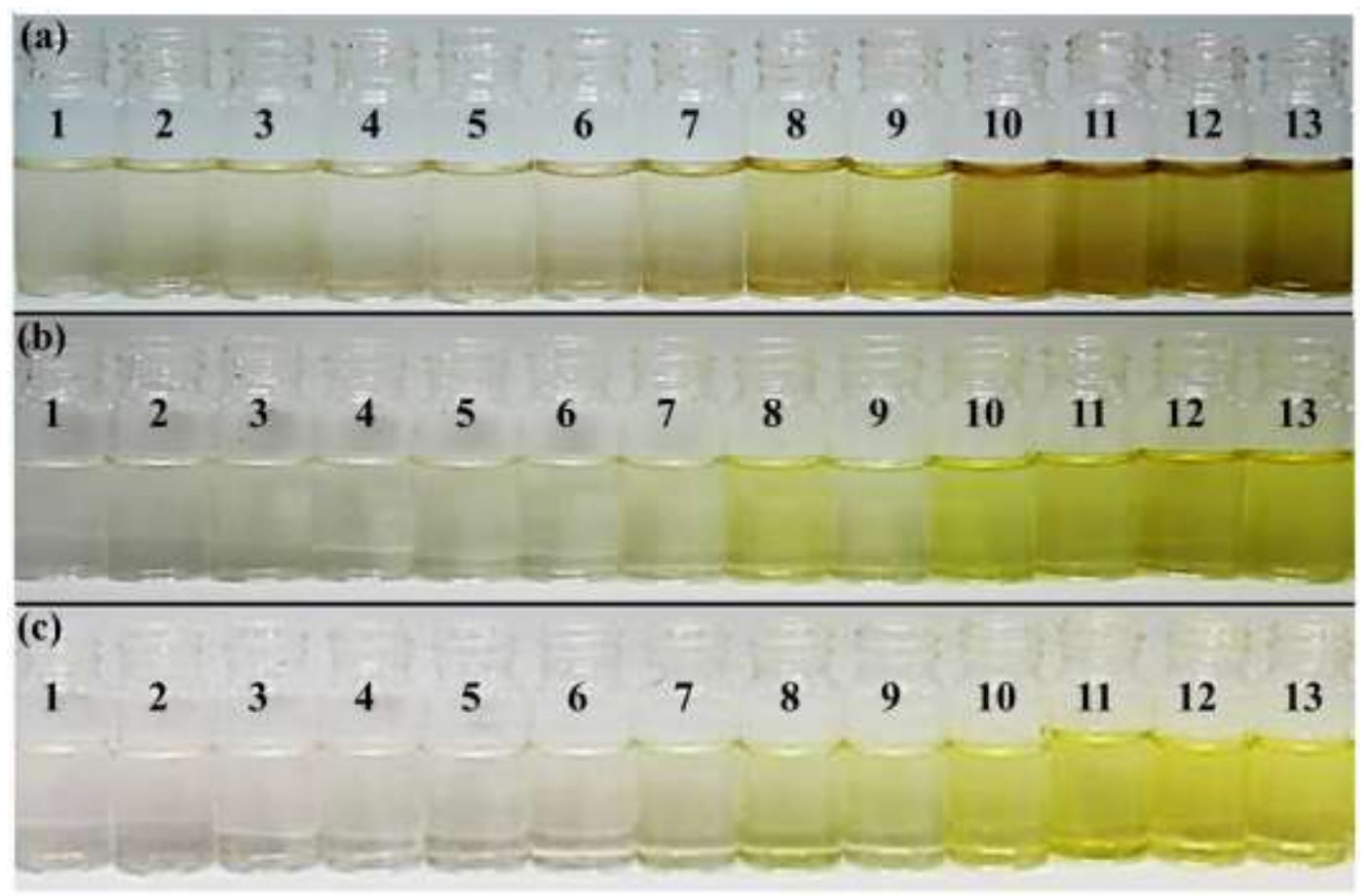

Fig. 1. Color change of buffer solutions in $\mathrm{pH}$ values from 1 to 13 added (a) AAC, (b) CJL and (c) SJM.

\section{RESULTS AND DISCUSSION}

The flower extracts of three flowers, A. auriculiformis A.
Cunn. (AAC), C. juncea L. (CJL) and S. javanica Miq. (SJM) have the coloring natural pigments such as subgroup of flavonoids and sensitive to $\mathrm{pH}$. From Fig. 1, the color 
changing trials in buffer solutions with various $\mathrm{pH}$ values from 1 to 13 show that color of acidic solutions are light brown, and $\mathrm{pH} 8$ and 9 solutions have sharper color for ACC extract as indicator. There is a dark brown color at $\mathrm{pH} 10-13$ of buffer solutions. For CJL and SJM extracts, the colors of buffer solutions were very light brown in $\mathrm{pH}$ values ranging from 1 to 6 and yellow for $\mathrm{pH}$ values from 7 to 13 . The test using $\mathrm{HCl} / \mathrm{NaOH}$ solutions and $\mathrm{CH}_{3} \mathrm{COOH} / \mathrm{NaOH}$ solutions with $\mathrm{pH}$ values from 1 to 14 was conducted in different $\mathrm{pH}$ solutions and then flower extracts were added (see Fig. 2 and Fig. 3). The results found that solutions have clear color in
$\mathrm{pH}$ values from 10 to 14 for $\mathrm{HCl} / \mathrm{NaOH}$ solutions (Fig. 2 (a)-(c)) and in $\mathrm{pH}$ values from 11 to 14 for $\mathrm{CH}_{3} \mathrm{COOH} / \mathrm{NaOH}$ solutions (Fig. 3 (a) - (c)). It is possible that there are the $\mathrm{pH}$ changes of solutions because the flower extracts have acidity of pH 5 approximately. The colors of acidic solutions of buffer solutions and $\mathrm{HCl} / \mathrm{NaOH}$ solutions are the same but the color of acidic solutions in $\mathrm{CH}_{3} \mathrm{COOH} / \mathrm{NaOH}$ solutions using CJL and SJM extracts as indicators is sharper than in buffer and $\mathrm{HCl} / \mathrm{NaOH}$ solutions, while using $\mathrm{AAC}$ in $\mathrm{CH}_{3} \mathrm{COOH} / \mathrm{NaOH}$ solutions produces a similar color to those of buffer and $\mathrm{HCl} / \mathrm{NaOH}$ solutions.

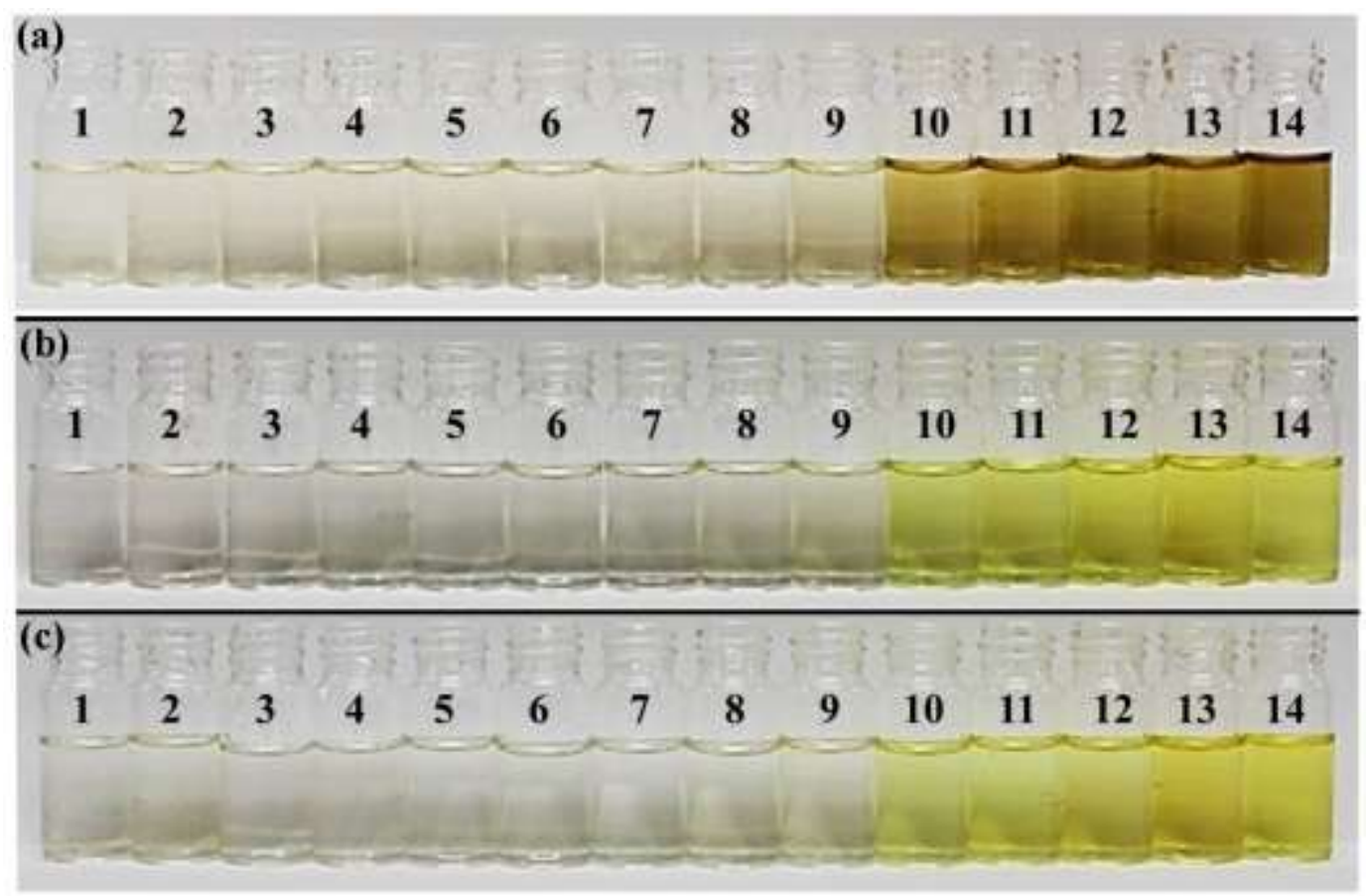

Fig. 2. Color change of $\mathrm{HCl} / \mathrm{NaOH}$ solutions in $\mathrm{pH}$ values from 1 to 14 added (a) $\mathrm{AAC}$, (b) $\mathrm{CJL}$ and (c) SJM.

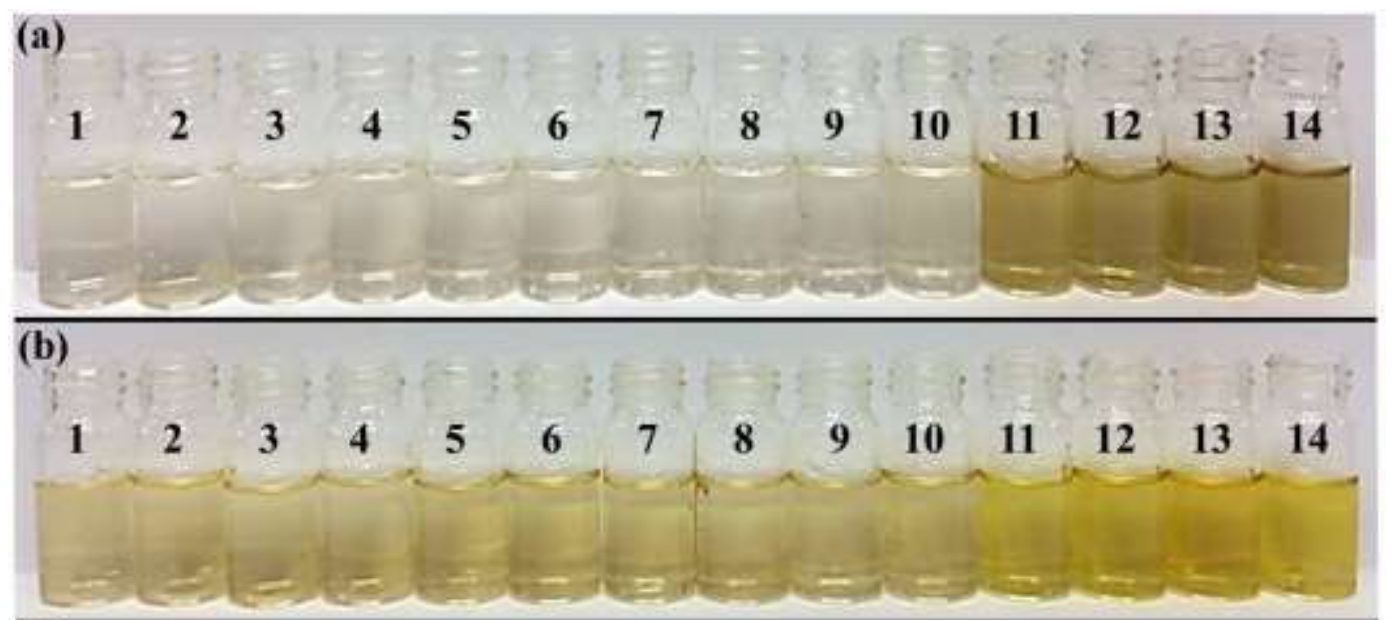

(c)

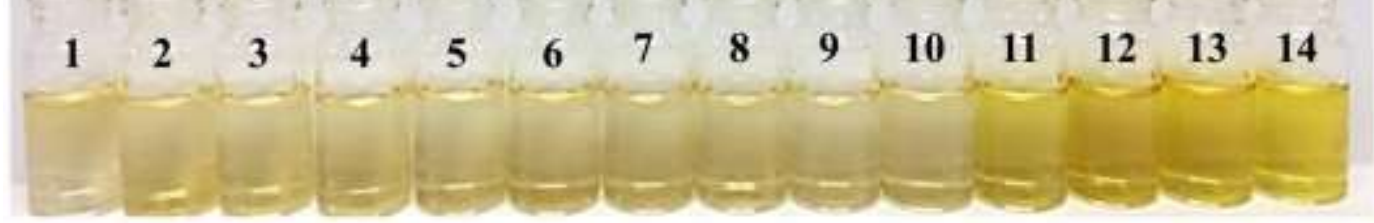

Fig. 3. Color change of $\mathrm{CH}_{3} \mathrm{COOH} / \mathrm{NaOH}$ solutions in $\mathrm{pH}$ values from 1 to 14 added (a) AAC, (b) CJL and (c) SJM.

The efficiencies of extracted indicators were determined by comparing acid-base titrations with the standard indicator (Phenolphthalein). The $\mathrm{pH}$ ranges of the color change of flower extracts are boarder than that of Phenolphthalein (Table I). Due to the color change of similar tone and $\mathrm{pH}$ range of extracted indicators (see Table I), strong acid-strong 
base titrations and weak acid-strong base titrations were specifically selected using titration of two concentrated-base titrants. In Table II, the end point of titrations obtained by flower extracts vary similarly to the end point, indicating an equivalent point, obtained by Phenolphthalein. When we increased the strength of strong base, the sharpness of color change was also increased. For the color change of solution, the yellow solution is observed more easily than the dark brown solution when the color of starting solution is light brown. The comparison of the color changes in acid-base titrations can be found in Fig. 4 and Fig. 5.

TABLE I: COLOR CHANGE AND PH RANGE INDICATORS

\begin{tabular}{cccc}
\hline \hline Indicators & Indicator color changes & $\begin{array}{c}\mathrm{NaOH} / \mathrm{HCl} \\
\text { (Titrant/Titrand) }\end{array}$ & $\begin{array}{c}\mathrm{NaOH} / \mathrm{CH}_{3} \mathrm{COOH} \\
\text { (Titrant/Titrand) }\end{array}$ \\
\hline Phenolphthalein & Colorless to Pink & $8.22-10.05$ & $8.22-10.01$ \\
AAC & Light Brown to Dark Brown & $6.66-11.37$ & $6.66-11.23$ \\
CJL & Light Brown to Yellow & $6.88-11.18$ & $6.88-11.55$ \\
SJM & Light Brown to Yellow & $6.78-11.25$ & $6.78-10.25$ \\
\hline \hline
\end{tabular}

AAC: A. auriculiformis A. Cunn., CJL: C. juncea L., SJM: S. javanica Miq.

TABLE II: SCREENING RESULTS OF ACID-BASE TITRATION WITH EXTRACT AS INDICATOR

\begin{tabular}{|c|c|c|c|c|c|c|}
\hline \multirow{3}{*}{ Indicators } & \multicolumn{4}{|c|}{ Mean values of titration \pm S.D. $(\mathrm{mL})^{*}$} & \multirow{3}{*}{ Indicator color changes } & \multirow{3}{*}{$\mathrm{pH}$} \\
\hline & \multicolumn{2}{|c|}{$\begin{array}{c}\mathrm{NaOH} / \mathrm{HCl} \\
\text { (Titrant/Titrand) }\end{array}$} & \multicolumn{2}{|c|}{$\begin{array}{c}\mathrm{NaOH} / \mathrm{CH}_{3} \mathrm{COOH} \\
\text { (Titrant/Titrand) }\end{array}$} & & \\
\hline & $0.5 \mathrm{M} \mathrm{NaOH}$ & $1 \mathrm{M} \mathrm{NaOH}$ & $0.5 \mathrm{M} \mathrm{NaOH}$ & $1 \mathrm{M} \mathrm{NaOH}$ & & \\
\hline Phenolphthalein & $29.19 \pm 0.06$ & $14.56 \pm 0.11$ & $29.29 \pm 0.11$ & $14.64 \pm 0.11$ & Colorless to Pink & $8.22-10.05$ \\
\hline $\mathrm{AAC}$ & $29.16 \pm 0.08$ & $14.60 \pm 0.09$ & $29.10 \pm 0.05$ & $14.73 \pm 0.11$ & Light Brown to Dark Brown & $6.66-11.37$ \\
\hline CJL & $29.12 \pm 0.01$ & $14.67 \pm 0.09$ & $29.43 \pm 0.13$ & $14.81 \pm 0.09$ & Light Brown to Yellow & $6.88-11.55$ \\
\hline SJM & $28.99 \pm 0.12$ & $14.56 \pm 0.04$ & $29.26 \pm 0.14$ & $14.61 \pm 0.09$ & Light Brown to Yellow & $6.78-11.25$ \\
\hline
\end{tabular}

$*$ All values are mean \pm S.D. of 5 readings

AAC: A. auriculiformis A. Cunn., CJL: C. juncea L., SJM: S. javanica Miq.

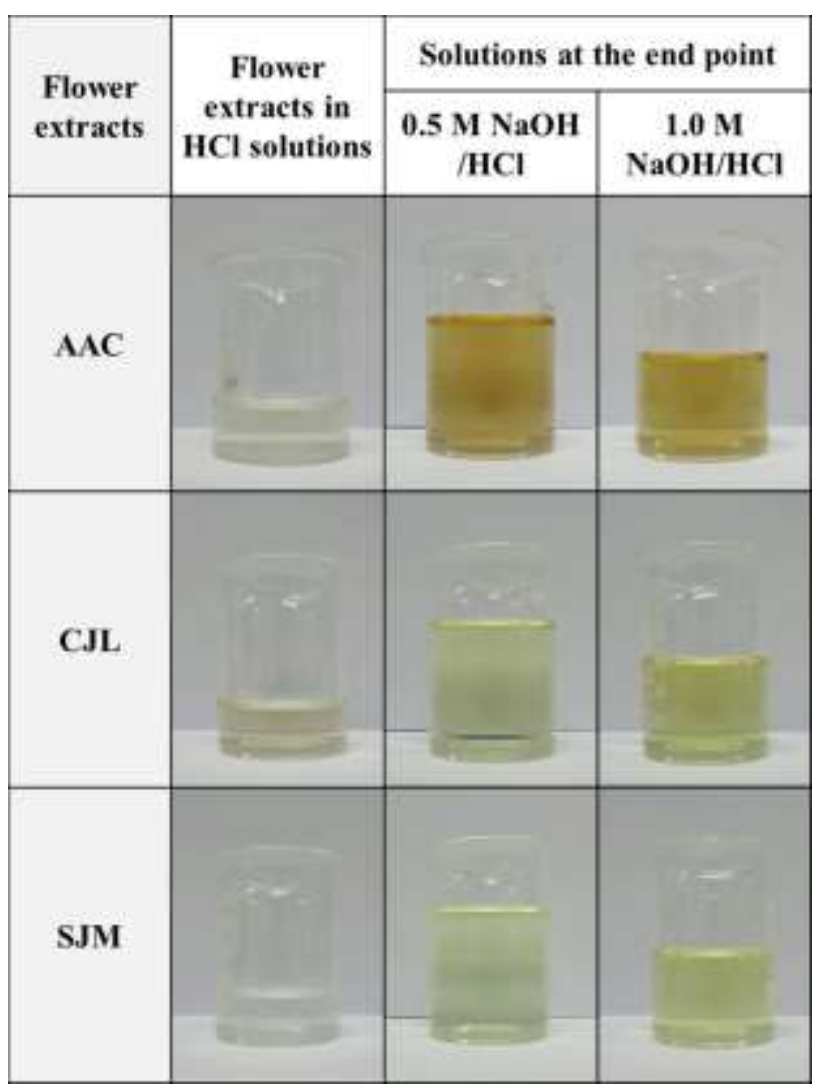

Fig. 4. Color change of strong acid - strong base titrations.

This study suggests the usefulness of three flower extracts in acid-base titrations, especially the case of strong acid-strong base titrations and weak acid-strong base titrations using the flower extracts as indicators that yielded a result which is very similar to that of standard indicators. Based on all above results, this study confirmed that all flower extracts can be used as acid-base indicators that can replace phenolphthalein indicator because these natural indicators are cheap, safe and easy to prepare, whereas synthetic indicators were found to be more expensive and hazardous. Therefore, this is a new application of these three flowers as local materials that can be found easily in Thailand.

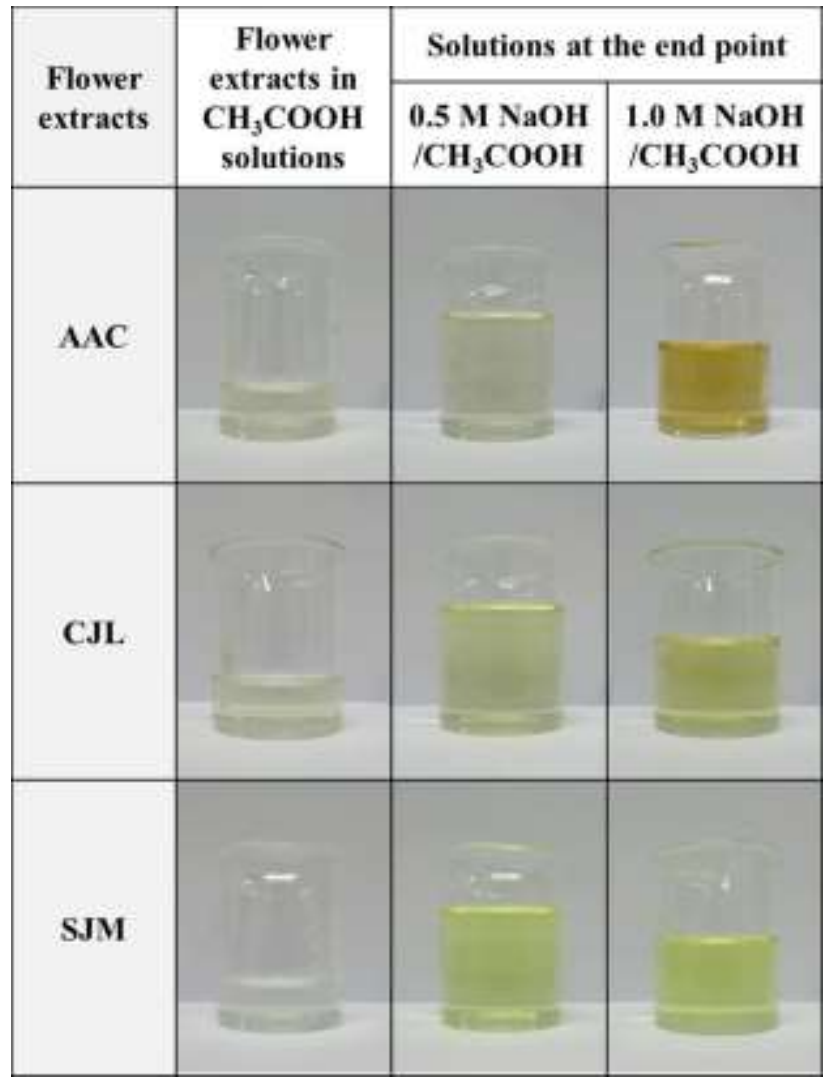

Fig. 5. Color change of weak acid - strong base titrations. 


\section{CONCLUSIONS}

Three Thai flowers, A. auriculiformis A. Cunn. (AAC), $C$. juncea L. (CJL) and S. javanica Miq. (SJM), can be used as a natural indicator according to the initial study that tested the color change in $\mathrm{pH} 1-13$ of buffer solutions, $\mathrm{pH} 1-14$ of $\mathrm{HCl} / \mathrm{NaOH}$ solutions and $\mathrm{pH} 1-14$ of $\mathrm{CH}_{3} \mathrm{COOH} / \mathrm{NaOH}$ solutions. Moreover, flower extracts were used in real acid-base titration, strong acid-strong base titrations and weak acid- strong base titrations in which titrants are the strong base $(\mathrm{NaOH})$. The results indicate that these extracts can be used to replace the standard indicator (Phenolphthalein) because the end point is very close to the standard indicator. The increase in the strength of the strong base also increased the sharpness of color change. During titration, solutions have more basicity and the colors of solutions were changed from light brown to dark brown for ACC, and altered from light brown to yellow for CJL and SJM. Therefore, this investigation found a new application of three flowers which can be a natural indicator that is eco-friendly, easy to prepare and cheap. Finally, they can be used in the chemistry class and simply tested at home.

\section{ACKNOWLEDGMENT}

We appreciate the Faculty of Education and Faculty of Science and Technology, Bansomdejchaopraya Rajabhat University, for supporting chemical equipment and a laboratory.

\section{REFERENCES}

[1] W. D. Whitney, "Titration," in The Century Dictionary and Cyclopidia, vol. 8, B. E. Smith, Ed. New York: The Century Co., 1899, pp. 6357-6358.

[2] D. Harvey, Modern Analytical Chemistry, 1st ed. Boston: McGraw-Hill, 2000, ch. 9, pp. 273-274.

[3] K. W. Whitten, R. E. Davis, M. L. Peck, and G. G. Stanley, Chemistry, 9th ed. Belmont, CA: Cengage Learning, 2010, ch. 11, pp. 379-381.

[4] D. C. Harris, Acid-Base Titrations, Quantitative Chemical Analysis, New York: Craig Bleyer, 2007, p. 199.

[5] Tukiran and A. P. Wardana, "Thunbergia erecta L. flower as an alternative acid-base natural indicator," Rasayan J. Chem., vol. 11, pp. 773-779, 2018

[6] S. H. Bhise, N. G. Shinde, B. S. Surve, N. V. Pimpodkar, and S. S. Shikalgar, "Acalypha wilkesiana as natural $\mathrm{pH}$ indicator," Int. J. Nat. Prod. Res., vol. 4, pp. 33-35, 2014.

[7] A. Bala, N. Muhammad, M. Idris, and K. Khalid, "Phytochemicals screening and acid-base indicator property of ethanolic extract of Althea rosea flower," J. Adv. Sci Res., vol. 7, pp. 30-32, 2016.

[8] S. I. R. Okoduwa, L. O. Mbora, M. E. Adu, and A. A. Adeyi, "Comparative analysis of the properties of acid-base indicator of Rose (Rosa setigera), Allamanda (Allamanda cathartica), and Hibiscus (Hibiscus rosa-sinensis) flowers", Biochem. Res. Int., vol. 2015, pp. $1-6,2015$.
[9] A. K. Sekhon, S. Sohal, S. Arora, and H. Kaur, "Acacia auriculiformis: A gamut of bioactive constituents against Bactrocera cucurbitae," Int. J. Pure Appl. Zool., vol. 2, pp. 296-307, 2014.

[10] A. E. Al-Snafi, "The contents and pharmacology of Crotalaria juncea-A review," IOSR J. Pharm., vol. 6, pp. 77-86, 2016.

[11] S. Tangvarasittichai, N. Sriprang, T. Harnroongroj, and S. Changbumrung, "Antimutagenic activity of Sesbania javanica Miq. flower DMSO extract and its major flavonoid glycoside," Southeast Asian J. Trop. Med. Public Health, vol. 36, pp. 1543-1551, 2005.

[12] J. M. Bueno, P. Sáez-Plaza, F. Ramos-Escudero, A. M. Jiménez, R. Fett, and A. G. Asuero, "Analysis and antioxidant capacity of anthocyanin pigments. Part II: Chemical structure, color, and intake of anthocyanins," Crit. Rev. Anal. Chem., vol. 42, pp. 126-151, 2012.

[13] S. Singh, S. B. Bothara, and S. Singh, "Acid-base indicator properties of dyes from local flowers: Cassia aungostifolia Linn., Thevetia peruviana (Pers.) K. Schum and Thevetia thvetiodes (Kunth) K. Schum," Pharmacogn. J., vol. 3, no. 19, pp. 35-39, 2011

[14] Preparation of $\mathrm{pH}$ buffer solutions. [Online]. Available: http://delloyd.50megs.com/moreinfo/buffers2.html

[15] R. A. Robinson and R. H. Stokes, "The measurement and interpretation of conductance, chemical potential, and diffusion in solutions of simple electrolytes," in Electrolyte Solutions, 2nd ed. Rev, London Butterworths, 1968.

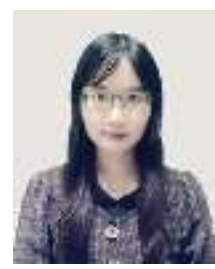

Naruwan Pattarapongdilok is a lecturer at Chemistry Program, Department of Science, Faculty of Science and Technology, Bansomdejchaopraya Rajabhat University, Thailand. She holds a bachelor's degree and a master's degree in chemistry from Chulalongkorn University. Her research interests include natural product chemistry and chemistry education.

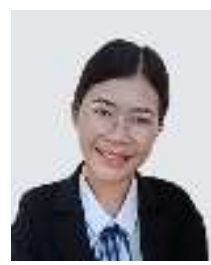

Primpak Malichim completed the bachelor of education program in general science from Bansomdejchaopraya Rajabhat University (Thailand) in 2018. She was an assistant researcher for this research in 2017. She has interested in natural product chemistry.

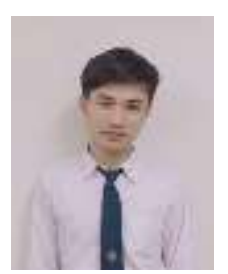

Natthaphol Simmee completed the bachelor of education program in general science from Bansomdejchaopraya Rajabhat University (Thailand) in 2018. He was an assistant researcher for this research in 2017 . He has interested in natural product chemistry.

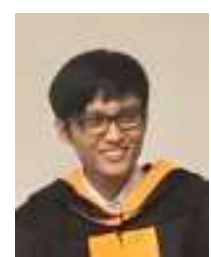

Jirapast Sichaem is a lecturer at Department of Chemistry, Faculty of Science and Technology, Thammasat University, Thailand. He holds a bachelor's degree in chemistry from Naresuan University. He earned a master's degree and a Ph.D in chemistry from Chulalongkorn University. He has his expertise in the fields of cytotoxic, antioxidant, antidiabetic and anti-Alzheimer's compounds from Thai medicinal plants. 